\title{
The Influence of Capitalism in the Labor Force Logic of the Female Prison System and the Effectiveness of Work Programs for Reintegration
}

\author{
Yuri Fedrigo Dutra \\ Pontifícia Universidade Católica do Paraná, Brazil \\ R. Imaculada Conceição, 1155 - Prado Velho, Curitiba - PR.
}

\begin{abstract}
Work programs in the female prisons of Brazil are far from promoting participants' dignity, their learning new marketable skills, or even providing a potential source of remuneration. The real effect of prison work programs is inflicting a painful conscience and imposing atonement. Critical criminology presents the actual ineffectiveness of prisons and demystifies how capitalism influences thinking about work in European, North American, and Brazilian jails. Concerning female prisons, critical criminology also reflects the androgynous character of laws, the inadequate architecture in prisons, and the improper work settings for women. Factual reality reveals programs offering unattractive work, focused on domestic chores, with low pay and no vocational focus, and that are subject to discontinuity due to policy changes in Brazilian prison administrations. Through bibliographic research with a descriptive inductive method, the first stage of this analysis seeks to carry out a theoretical approach to applying critical criminology on the influence of European and North American capitalism and subsequently the differential of Brazilian capitalism in the development of work programs in the prisons of these countries. Systematizing feminist criminology and its approach to prison issues in Brazil is the aim of the second stage of this analysis. In the third stage, through the description of empirical works carried out in some Brazilian states, the reality of women inmates inside the walls is presented. The resulting conclusions are that the moral nature of work, as conceived by European liberalism, does not fit into the Brazilian reality that retains traces of slavery and colonialism simultaneously with liberal capitalism. These characteristics are reflected in prisons, as they hold the lower-class population in inferior jobs and gives the inmates a poor-quality education. As a result, the work carried out in these programs is not intended to generate adequate compensation, much less emancipate participants, but rather neutralizes, stigmatizes, and exterminates them, as they perish in the worst possible living conditions in prison.Critical feminist criminology denounces the prison system in its architecture and its rules that do not aim at gender differentiation. Patriarchal policymakers and administrators have created this result with antiquated and conventional perspectives that have not considered gender differences and have failed to visualize female needs inside prisons. In practice, the work carried out by female inmates does not compensate them at levels comparable to the general labor market. Their remuneration is inadequate, and the work is unattractive. There is a discontinuity within the work programs because those who plan and implement them are political appointees, subject to turnover.The conclusion is that, in Brazilian women's prisons, there are few policies for the implementation of work with an emancipatory capacity such as vocational training that can be absorbed by the labor market outside of prison. Most of the skills obtained involve manual work and are focused on residential care. Other factors that block the goal of emancipation include a punitive attitude among policymakers that the State should not reward prisoners by providing training with the same compensation potential as free citizens. It also includes the lack of continuity of effective training and work policies due to the constant turnover of penitentiary managers by the prison system.
\end{abstract}

Keywords: Brazilian prison; critical criminology; female prison work

DOI: $10.7176 /$ RHSS/11-11-01

Publication date:June $30^{\text {th }} 2021$

\section{Introduction}

Work in the capitalist world helps with the survival, accumulation of wealth, and dignity of the human being. However, in prisons, the logic of labor is different. Some American and European theorists have observed how capitalism has influenced prison labor in various historical intervals, sometimes serving as cheap labor, and other times serving as an atonement for the inmates' past conduct. Brazilian capitalism was developed later and valued the ideas of a social protection ideology reflected in critical criminology. These ideas of instituting work programs included advanced techniques for the insertion of ex-offenders into the labor market to reward the imprisoned person who could, in turn, come out of the misery in which they lived before being arrested. The reality shows an inverted efficacy. Instead of the declared function of resocialization and reintegration into society, the atonement for the offender's criminal conduct and mainly their neutralization remains.

In contrast, female criminology and some empirical works carried out in the Brazilian states of Santa Catarina, Rio de Janeiro, São Paulo, Paraná, and Maranhão reveal the androgynous character of the laws, the 
architecture of prisons, and the working logic that are poorly suited to women, because most of the time programs are directed to the domestic sector, having a low potential of reintegration into the real labor market outside of the walls. In this context, it is questionable whether the female prison system is pursuing its declared function of reeducating and re-socializing inmates through the occupational work sector.

A hypothesis could be that the prison system, especially the female one, has no work program activities with emancipatory properties, and does not effectively reintegrate the incarcerated after their release due to the ideological factor of social protection, delayed capitalism, and Brazilian clientelism. Therefore, the real objective revealed, with a critical criminology assessment, is the actual reality of female work activity in the prison system and its ineffectiveness for their reintegration and reinsertion into the community.

This article proposes, in the first stage, to carry out a brief survey of the theories of capitalism that directly influenced the form of workshops' development in European and American prisons, and to subsequently review the work of Brazilian theorists to show how the ideology of vocational workshops was structured inside prisons with the distinct influence of Brazilian capitalism. In the second stage, the intention is to systematize the construction of feminine criminology using gender studies and the authors' studies that addressed the topic related to prisons. To do so, it will be shown how the laws and the female architecture are structured inside the androcentric world of the law and prisons and will conclude with the liberalist market bias in the analysis of female work in prisons. In the third stage, the approach will be a review of empirical studies done inside of the prisons of the States of São Paulo, Rio De Janeiro, Paraná, Santa Catarina, and Maranhão. The empirical studies aim to move away from the formal reality of laws and existing programs to approach the material reality of labor inside the prisons to present how the vocational workshops are structured, what their real function and effectiveness are, and how they support subsidies for the future internal and public policies.

\section{Methodology}

The methodology used is bibliographical research with citations of ethnographic research and inductive reasoning. In the first stage, through bibliographical research, we have sought to investigate how the capitalist approach of production influences the management and functions of reeducation and resocialization, in European and American prisons and to then present the differential of Brazilian capitalism characterized by Late Liberalism, and the ideology of social protection and social immobility. The same methodology is applied for the presentation of the impact by the critical female criminology on women's prisons to demonstrate the androgynous character of the laws aimed at this sector, the inadequate architecture in the prisons, and the unsuitable work environments for this gender. The methodology applied in the third stage is the report of some ethnographic research conducted in prisons in the Brazilian states of Santa Catarina, Rio de Janeiro, São Paulo, Paraná, and Maranhão aiming to show the factual reality of the work of women in prisons and their differentiation from the male universe.

\section{Results}

1 The historiographical assessment of jail as a factory and the influence of capitalism in the vocational workshops in prisons

The prison system, since its creation, has never achieved its goal of reeducating and re-socializing inmates. It is arguable whether correction establishments have somehow fulfilled their stated purpose of rehabilitation and of bringing the detainees back to a normal social life. (Note 1)

At the beginning of capitalism in Europe, with an excess of people in prisons and the need for qualified manpower for employment in industries, the goal of prisons was to train people. The opposite occurred during the great capitalist crises, dating back to the industrial revolution, which was characterized by an excess of labor. Prison became the place of corporal punishment and torture. Human life did not have any social relevance at that time, and there was cheap and abundant labor outside the prisons.

In the sixteenth century, the possibility of using the workforce of convicts arose. (Note 2)

After the decrease in labor, the prison structure changed, and torture returned. These shifts of work and punishment inside the prisons were observed by the theorists Rushe, Kirchheirmer, and Foucault. It should be noted that the return of torture, in the modern age, reveals that the Middle Ages in Criminal Law was never revoked, thus leading to the conclusion that the democratic ideal of the Rule of Law has influenced all other areas of civil law, but the Criminal Law insists on upholding the ideals of the Middle Ages.

Looking at another historical period, with the globalization of culture (Note 3) and the reorganization of capitalism under so-called neoliberalism, the state of social welfare began to disintegrate, with large pockets of misery rising and influencing prison policy. Penalizing convicted criminals and subjecting them to the structure of the penance state instead of the welfare state was viewed as more economical.

This approach was the measure taken by the US government. The solution for mass unemployment was the dismantling of the welfare state, imposing work requirements (Note 4), and increasing the prison population generated by a period of lean times in the public sector (Note 5). The United States chose to build jailhouses and 
prisons for its poor instead of dispensaries, day-care centers, and schools. (Note 6)

Although scholars such as Loicq Wacquant and Nills Christie have analyzed the vision of European and American punitive power, a Latin American view, with the perspective of the Brazilian reality, is necessary. Pavarini, like Barata, also has warned that one should study the Criminology of what occurs in Brazil and present solutions based on that reality.

It cannot be denied that, even in Brazil, the great advantage that always existed was a low-cost labor force of convicts. However, in modern-day Brazil, prisons do not always have vocational workshops or companies that operate inside of them. There is also the ideology that these workshops do not necessarily create real professional growth and true reintegration. This ideology is strongly disseminated among prison employees, including directors and officers. For them, what must prevail is atonement and the infringement of rights; these are effective means of incarceration.

The morality of work, with the liberal European intent, does not fit the Brazilian reality that still maintains the remnants of slavery of "Casa Grande e Senzala" (Note 7). This reality, along with a veneer of liberal capitalism conceptualized by Faoro (Note 8), maintains a form of clientelism (Note 9) and insists on keeping the lower classes in subaltern jobs and inadequate education. Sérgio Buarque de Holanda stresses that reform movements in Brazil have always been top-down with people being disillusioned. For them, there was the notion that achieving literacy should suffice.

In respect to the Brazilian reality, Pavarini states that the origin of a perceived dangerous class in Brazil reflects the country's origins that included the institutions of slavery (Note 10). Slavery, associated with the reality of liberal capitalism in Brazil, has led to the notion that our prisons and the work done in them are not intended to generate profits, let alone to emancipate the inmates, but rather to neutralize, stigmatize, and exterminate them. Pavarini states that prison is a completely delegitimized institution in a democratic and liberal social context because it cannot intervene, prevent, or readapt the behavior of inmates. Rather, it is a machine for the reproduction of inequality, and it is a school of crime. (Note 11)

The capitalist reality intended for prisons in Europe was never successful in Brazil. The latter offers differentiated capitalism with a strong appeal to clientelism and elitism that supports a form of conservatism offering to protect upper-class Brazilian families from losing their privileges. Thus, if families do not want to lose their privileges, how could the lower classes, especially the "vagrants" and those banned to the prisons be allowed by the state to ascend through quality educational or professional training?

In the context of Brazilian capitalist liberalism analysis, Raymundo Faoro states that: The family, not the individual, nor the State or any trading company, has been the great colonizing factor in Brazil since the 16th century. (Note 12)

Brazilian capitalism, as Raimundo Faoro argues, was a construction that did not allow injustices to be corrected, but rather that privileges be maintained. That is why reverse effectiveness prevails in Brazilian prisons. Brazilian capitalism is derived from conservative liberalism, where privileges cannot reach the subaltern classes. To bring the ideal of European liberalism into the 21 st century to Brazil requires fulfilling the ideals of justice, equality, and freedom especially in an area of criminal law, which still maintains an archaism of the middle ages (Note 13). The ideals of modernism have not yet been fulfilled even amid the postmodern era.

\section{Feminist criminology and gender approach to prison issues}

In Brazil, the patriarchal government repression against women occurs more strongly in the criminal system including the elaboration of criminal laws. The legal discourses of the defense and prosecution of crimes committed by and against women focus on patriarchalism and victimization binomial, as well as in a series of human rights violations related to the universalization of laws that do not properly protect gender differences. (Note 14) This reproduction of patriarchal repression happens in all sectors of society and is not so different from the reality of the female prison.

The goal of job training in women's prisons, with the ideological bias of the capitalist system of production alternates between its productive effectiveness and punitive character. However, the following differential is observed: when vocational workshops are given in women's prisons, they are typically aimed at the personal sphere, such as the domestic environment or the "female universe". The training is exemplified in the development of skills for domestic chores and beauty salon tasks and rarely in emancipatory works, that are focused on the independence of the incarcerated. When prisons do not offer vocational workshops, the work performed by female inmates assumes a punitive form of dull activities such as assembling clothespins. Thus, work in female prisons suffers patriarchal repression in the sense that training does not match that of men. As a result, the training cannot be absorbed by the labor market or provide financial security. Thus, the female moral imperative to be good housewives and care for their beauty distances them from the objective of re-socialization and emancipation. 


\section{Field research analysis of female prison work}

Several researchers in the field of sociology, anthropology, and law have entered the field of training programs in Brazilian prisons to carry out empirical studies (Note 15). Having been carried out in different prisons and in different historical moments, the experiences and observations of these studies serve to guide other works. As a result, the answers, observations, and policies developed in the proposed selection of studies herein will be differentiated. That is the value of multidisciplinary work in empirical research supporting critical criminology. The researcher Brant in his book classifies three types of work in the prisons of São Paulo: the workshops, the employers, and the services of operation and maintenance of the prison.

In the workshops, the equipment is provided by the prison itself or by a supporting foundation. However, most of the equipment is disabled. Even when operational, they are meant to meet the internal needs of the prison. Remuneration is uniformly poor and does not even match the requirements of applicable criminal laws themselves. (Note 16)

Work for employers is primarily where one prisoner is the boss of another or where there are multiple situations of subordination. For example, one prisoner is the owner of a cell and another must pay to live in it by performing various types of work. Or the prison management receives an order from a private firm sewing ball, and the prisoner "boss" is in charge of calling other prisoners to perform the service. They in turn receive lower amounts of compensation from the "boss". In any event, the prison administration retains most of the pay in these arrangements.

Lemgruber presents her empirical view of the work that occurred in the prison of Rio de Janeiro. In her observation, she states that the remuneration received for prison work is derisory and is arbitrarily established by the director and the outside contracting firm. Besides, there is a fee collected by the prison, which ranges from 20 to $50 \%$. With this withholding of the work's value, the prisoners feel robbed by prison authorities. (Note 17)

Operating and maintenance services, however, do not provide compensation, but may be a way of having access to legal services, benefit requests, and permits for release. The reality found in the penitentiaries is that convicts are chosen for work not based on equality or equity, but for better behavior. Lemgruber refers in her work in Rio de Janeiro to show how favoritism is used. The prison's director selects the inmate for an available job. In this process, not even the social worker participates. Although there is a regulation regarding a detainees' right of equal opportunity to be chosen, what prevails is the interest of the institution. (Note 18)

It is also observed that not all prisoners have access to work inside prisons. In the data analysis performed by INFOPEN-MJ/DEPEN-2008, Julião shows that, in 2008, the prison population was 381,112 people and $23.95 \%$ of these were in vocational work programs. Since then, the prison population has increased, but the percentage of people in vocational workshops has decreased. In the July to December 2019 period, the prison population was 748,009 and the number of inmates in vocational programs was 144,211 or $19.28 \%$. This percentage has remained since 2017. (Note 18) (Table 1)

The data demonstrate the disregard of the Brazilian prison system for the Sentence Execution Act which provides that all inmates should be participating in some vocational activity with an instructive and training component. These data are associated with the reality of the shortage of professionals who work in the prison system. Rather, the administration and maintenance of these programs are passed on to trusted detainees. (Note 20)

Moreover, prison work cannot be an effective means of reintegration into society. Julita Lemgruber, in her book Cemitério dos vivos: análise sociológica de uma prisão de mulheres, written in 1983, concludes that prison work becomes a way of generating wealth for the prison system by lowering its costs and having occupational activities that occupy the detainees' time, and thus, prevent inactivity and diverts them from engaging in illicit internal activities. (Note 21)

Still, a poorly developed and underpaid job in a prison can cause discouragement and a feeling of uselessness or a form of psychological torture. Also, it perpetuates the slave-based society, previously referenced, which Brazil has not completely abandoned in its criminal law.

Brant observed that, while work in prisons resembles that of the external labor market, he also points out that internal activities never prove to be identical to the external reality. Prisoners' work is boring, it produced psychological torture, and it is useless. Examples of this type of work are: "placing springs on clothespins or umbrellas, packing plastic straws, folding envelopes or boxes, and sewing leather balls." (Note 22)

For women's work, there is rarely emancipatory vocational training. The main occupational activities are mixed with the few vocational workshops, leaving the participants to perform "art, handcrafts, simple techniques, computing, formal instruction, and foreign languages" (NOTE 23), beauty salon techniques, and illegal activities such as the sale of drugs (Note 24). "Work considered manual labor is characterized by monotony and repetition, and they do not offer any attraction," (Note 25)

In São Luís, in the 2011 administration, the vocational workshops were geared to reintegration into society. They included the following: Workplace Safety, Electronics, Electrical-electronics Maintenance, Telecommunications and Electrical Installations, PVC Lining Application, Structural Company, Administrative 
Assistant, Retail Service, Accounting Assistant, Cooking, Crafts, Installation of Spokes on Bicycle Wheels (Note 26). However, with the change of administration in the Department of Public Security, the policies developed by former managers were discontinued by prison directors and new workshop coordinators. Therefore, at the time the surveys were carried out, in 2012, the prison was going through a transitional phase to the new policies, and no workshops were operational.

Consequently, despite having national legislation, embodied in the Sentence Execution Act standardizing prison work, there is a heterogeneity of its application and interpretation in each State and that is reflected in prison management policies and their application of different labor policies. It is also observed that the Department of Public Security, responsible for the management of the Act, is a political body. Therefore, its secretaries and prison directors are subject to removal at any time which directly influences the training sector and the continuity of its projects.

The conclusion is that in Brazilian female prisons there are few policies for the implementation of work with an emancipatory aim. There is a strong representation of the ideology of social protection in the practices of managers, agents, and collaborators of prison policies, mixing punitiveness with Brazilian clientelism.

This ideology reflects the thinking that the State should not treat prisoners with the same citizenship rights, gender specificities, and employability that free citizens possess. Consequently, social immobility and distancing from the real re-socialization and re-education function of prisons is reinforced. The above ideological foundation supports the latent ineffectiveness of prisons and their unsanctioned policies of forcing inmates to demonstrate atonement and experience painful, soul-degrading punishment for their criminal conduct.

\section{Conclusion}

This article intended, with a critical criminology bias, to present the reality of female training and labor activity in the Brazilian prison system and its ineffectiveness for their reinstatement and reintegration into the community. In years that were influenced by the European capitalist mode of production, vocational training was used to meet the need for labor. However, with the scarcity of work in the labor market in later years, work and training were replaced by more punitive and degrading activities causing pain and distress to both the prisoners' minds and body. American globalization and neoliberal capitalism provided an example for bankrupting the welfare state and resulted in policies of social control and crime containment by repressive means. These approaches became highly profitable compared to investments in the welfare state such as citizenship, education, and personal emancipation.

Prison work in Brazil has a historical and ideological bias with traces of clientelism, which hinders its emancipatory character and is consistent with its punitive function. The arrival of late capitalism and greater support for democracy led to discussions about emancipation and the ideals of quality prison work and training with the goals of resocialization and an effective, functional return to society. However, these new policies were perceived to conflict with the simultaneously false perception that they would result in the removal of privileges from good, law-abiding people, who have never committed crimes and do not require the same opportunities for training as those inside of the prison.

In the second stage, the intention was to present a brief history of the requirements of the female prison inmates and how this issue is addressed in criminology. The main guidelines of Brazilian criminology were presented and how the architecture of and legislation governing prisons reveals their androcentric character. These controlling factors do not aim at accommodating gender differentiation in the elaboration of laws or legal practices. In prisons, the reality usurps the needs of women, such as the absence of spaces to exercise motherhood functions including insufficient nurseries, as well as limited hygienic material. In the labor sector, the work offered is mostly reduced to activities such as crocheting and knitting, and, at most, learning beauty salon skills.

In the third stage, the objective was to show the factual reality of the female prisons through some ethnographic research. Studies indicated that the work done by the female detainees is not comparable to the job market in general. Its remuneration is low, and the work is not attractive. The labor sector, especially the female sector, presents few opportunities for women with poor training in crafts. Despite this reality, most of the workshops in women's prisons include typically low-paying female activities such as arts and crafts or activities focused on domestic chores or beauty care. This stage also observed the lack of continuity of effective training and work policies due to the constant change of management by the prison system.

The conclusion is that in the Brazilian female prisons there are few policies for the implementation of work with an emancipatory aim. There is a strong representation of the ideology of social protection in the practices of managers, agents, and collaborators of prison policies, strengthening punitivism mixed with Brazilian clientelism.

This ideology is translated into the thinking that the State should not treat prisoners with the same citizenship rights, gender specificities, and employability that free citizens possess. Consequently, social immobility and the distancing from the real re-socialization and re-education function of prisons is reinforced, 
causing their ineffectiveness.

\section{References}

Andrade, Vera Regina Pereira de. (2005). A soberania patriarcal. O sistema de justiça criminal no tratamento da violência sexual contra a mulher. Seqüencia: estudos jurídicos e políticos. 50, 71-102

. (2006) Minimalismos, abolicionismos e eficienticismo: a crise do sistema penal entre a deslegitimação e a expansão. Seqüência: estudos jurídicos e políticos, Florianópolis. 52, 163-182

. (2003) Sistema Penal máximo X cidadania mínima: Códigos da violência na era da globalização. Porto Alegre: Livraria do Advogado Editora.

Arguelo, Katie.(2006). Uma abordagem criminológico crítica das finalidades subjacentes à pena de prisão. Revista Espaço Acadêmico, mensal, ano http://www.espacoacademico.com.br/067/67arguello.htm acesso em 31/03/2013.

. (2009). Criminologia e Crítica: Debates Atuais- Entrevista com Máximo Pavarini. Revista da Faculdade de Direito UFPR/ Universidade Federal do Paraná, Programa de Pós-Graduação em Direito, Curitiba, 50, 197- 222

Baratta, Alessandro. (1999). Criminologia Crítica e Crítica do Direito Penal: introdução à sociologia do direito penal. Tradução: Juarez Cirino dos Santos. (2 ed.) Rio de Janeiro: Instituto Carioca de Criminologia.

. (1999). O paradigma de gênero: da questão criminal à questão humana., IN: Criminologia e Feminismo, a cargo de Carmen Hein de Campos, Sulina, Porto Alegre, p 68-9

(2013). Ressocialização ou controle social: uma abordagem crítica da reintegração social do sentenciado. Alemanha. Disponível em: www.eap.sp.gov.br/pdf/ressocializacao.pdf. Acesso em: 30 maio 2013

Bauman, Zygmunt. (1999). Globalização: As consequências humanas. Tradução, Marcus Penchel. Rio de Janeiro: Jorge Zahar Ed.

Brandt, Vinícius Caldeira. (1994). O trabalho encarcerado.Rio de Janeiro: Forense.

Carvalho, José Murilo de. (1997). Mandonismo, coronelismo, clientelismo: uma discussão conceitual. DADOS Revista de Ciências sociais. Rio de Janeiro, v. 40, nº 02, 229 - 250.

Conselho Nacional de Justiça. CNJ. Programas de ação. Projeto começar de novo. http://www.cnj.jus.br/programas-de-a-a-z/sistema-carcerario-e-execucao _ penal/pj-comecar-de-novo. Available in 29/06/2013.

Christie, Nils. (1998). A indústria do controle do crime: a caminho dos GULAGS em estilo ocidental. Trad. De Luís Leiria. Rio de Janeiro: Forense.

Dutra, Yuri Frederico. (2006). A condição feminina perante o sistema de justiça criminal nos crimes contra os costumes. Grupo de trabalho: Movimentos sociais urbanos e o socialismo no século XXI . www.uel.br/grupo-pesquisa/gepal/.../yurifredericodutra.pdf

. (2011). Como se estivesse morrendo: A prisão e a revista intima realizada em familiares de presos. Rio de Janeiro: Editora Lumen Juris.

Faoro, Raymundo. (1993). A aventura liberal numa ordem patrimonialista. Revista USP.

$17,14-29$

Faoro, Raymundo. (2001). Os Donos do Poder: Formação do patronato político brasileiro. (3 ${ }^{\mathrm{a}}$. Ed). Rio de Janeiro: O Globo.

Freyre, Gilberto.(1998). Casa-Grande \& Senzala. (34 ${ }^{\mathrm{a}}$. ed.).Rio de Janeiro: Editora Record.

Fernades, Silvia dos Santos. (2005). As mulheres encarceradas no presídio Feminino de Florianópolis-SC: O cotidiano e os desejos. Trabalho de Conclusão de Curso (Ciências Sociais) - Universidade Federal de Santa Catarina

Heilborn, Maria Luiza. (1994). De que gênero estamos falando? Sexualidade, gênero e sociedade, Rio de Janeiro: CEPESC/IMS/UERJ, ano1, n.2.p.[...], 1994.

Holanda, Sérgio Buarque de.(1987). Raízes do Brasil. (19ª Ed.) Coleção Documentos Brasileiros. Prefácio de Antônio Cândido. Rio de Janeiro:José Olympio.

Julião, Elionaldo Fernandes. (2009). A ressocialização através do estudo e do trabalho no sistema penitenciário brasileiro. Tese (Doutorado) Instituto de Filosofia e Ciências Humanas. Universidade do Estado do Rio de Janeiro.

Lemgruber, Julita. (1983). Cemitério dos vivos: análise sociológica de uma prisão de mulheres. Rio de Janeiro: Achiamé.

Machado, Beatriz Piffer. (2013). Punição e ordem social. Considerações acerca das penalizações ao longo da história. Jus Navigandi, ano 13, n. 1937, 20 out. 2008. Available: http://jus.com.br/revista/texto/11841, (21 abr. 2013)

Melossi, Dario; Pavarini, Massimo.(2006) Cárcere e fábrica : As origens do sistema penitenciário (séculos XVI$X I X)$. Trad. Sérgio Lamarão. Rio de Janeiro: Revan: ICC. 
Oliveira, Olga Maria Boschi Aguiar de. (2016). Mulheres e trabalho: desigualdades e discricriminações em razão de gênero: o resgate do princípio da fraternidade como expressão da dignidade humana; Rio de Janeiro: Lumen Juris.

Rushe, George; Kirchheimer, Otto. (1999). Punição e Estrutura social. Tradução de Gisleine Neder. Rio de Janeiro: Freitas Bastos.

Saffioti, Heleieth; Vargas, Muñoz- (orgs). (1994). Mulher Brasileira É assim. Rio de Janeiro: Rosa dos Tempos: Brasília:Nipas.

Santos, Juarez Cirino dos.(2006). A Criminologia Radical. Curitiba: Lumen Juris, 2006 (2005). Teoria da pena: fundamentos políticos e aplicação judicial. Curitiba: IPCP: Lumen Juris.

Scott, Joan W. (1990). Gênero: uma categoria útil de análise histórica. Tradução Guacira Lopes Louro. Educação e Realidade. Porto Alegre, v.16, n. 2, 9.

(2005). O enigma da igualdade in Estudos Feministas, Florianópolis, p.13-30.

Soares, Bárbara Musumeci; Ilgenfritz, Iara. (2002). Prisioneiras: vida e violência atrás das grades. Rio de Janeiro: Garamond.

Wacquant, Löic. (2001). As prisões da miséria. Trad. André Telles. Rio de Janeiro: Jorge Zahar. Ed, 2001.

(2004). O Curioso eclipse da etnografia prisional na era do encarceramento e massa. Discursos Sediciosos: crime, direito e sociedade. Rio de Janeiro, n 13, 11-34.

Zaffaroni, Eugenio Raúl. (1991). Em busca das penas perdidas: a perda da legitimidade do sistema penal. Tradução Vânia Romano Pedrosa, Amir Lopes da Conceição. Rio de Janeiro: Revan.

\section{NOTES}

${ }^{1}$ Bauman, Zygmunt. (1999). Globalização: As consequências humanas. Tradução, Marcus Penchel. Rio de Janeiro: Jorge Zahar Ed. p. 118

${ }^{2}$ Rushe, George; Kirchheimer, Otto. (1999). Punição e Estrutura social. Tradução de Gisleine Neder. Rio de Janeiro: Freitas Bastos. p. 39

${ }^{3}$ Bauman, Zygmunt. (1999). Globalização: As consequências humanas. Tradução, Marcus Penchel. Rio de Janeiro: Jorge Zahar Ed. p. 118

${ }^{4}$ Wacquant, Löic. (2001). As prisões da miséria. Trad. André Telles. Rio de Janeiro: Jorge Zahar. Ed, 2001.p.77

${ }^{5}$ Wacquant, Löic. (2001). As prisões da miséria. Trad. André Telles. Rio de Janeiro: Jorge Zahar. Ed, 2001. p. 87

${ }^{6}$ Wacquant, Löic. (2001). As prisões da miséria. Trad. André Telles. Rio de Janeiro: Jorge Zahar. Ed, 2001. p. 88

${ }^{7}$ Freyre, Gilberto.(1998). Casa-Grande \& Senzala. (34 ${ }^{\mathrm{a}}$. ed.).Rio de Janeiro: Editora Record.

${ }^{8}$ Faoro, Raymundo. (2001). Os Donos do Poder: Formação do patronato político brasileiro. (3a . Ed). Rio de Janeiro: O Globo p. 819;827.

${ }^{9}$ Carvalho, José Murilo de. (1997). Mandonismo, coronelismo, clientelismo: uma discussão conceitual. DADOS - Revista de Ciências Sociais. Rio de Janeiro, v. 40, nº 02, 1997, p. 229 a 250. p. 231

${ }^{10}$ Arguelo, Katie. (2009). Criminologia e Crítica: Debates Atuais- Entrevista com Máximo Pavarini. Revista da Faculdade de Direito UFPR/ Universidade Federal do Paraná, Programa de Pós-Graduação em Direito, Curitiba, 50, p. 219

${ }^{11}$ Arguelo, Katie. (2009). Criminologia e Crítica: Debates Atuais- Entrevista com Máximo Pavarini. Revista da Faculdade de Direito UFPR/ Universidade Federal do Paraná, Programa de Pós-Graduação em Direito, Curitiba, 50, 199

${ }^{12}$ Faoro, Raymundo. (1993). A aventura liberal numa ordem patrimonialista. Revista USP.

n 17, p. 16

${ }^{13}$ The National Council of Justice (CNJ) has prepared a campaign called: The New Start which aims to raise awareness among public agencies and civil society to provide jobs and professional training courses for prisoners and ex-convicts in the prison system. The program's objective is to promote citizenship and consequently reduce the recurrence of crimes. For that, $(\mathrm{CNJ})$ created the Portal de Oportunidades. It is a website that gathers job vacancies and training courses offered to prisoners and ex-convicts. Opportunities are offered by both public institutions and private entities, which are responsible for updating the Portal. http://www.cnj.jus.br/programas-de-a-a-z/sistema-carcerario-e-execucao-penal/pj-comecar-de-novo

${ }^{14}$ Authors who worked on gender construction in this item were: Andrade, Vera Regina Pereira de. (2005) A soberania patriarcal. O sistema de justiça criminal no tratamento da violência sexual contra a mulher. Seqüência: estudos jurídicos e políticos. 50, 71-102; Heilborn, Maria Luiza. (1994) De que gênero estamos falando? Sexualidade, gênero e sociedade, Rio de Janeiro: CEPESC/IMS/UERJ, ano1, n.2.p.[...], 1994. Saffioti, Heleieth; Vargas, Muñoz- (orgs). (1994) Mulher Brasileira É assim. Rio de Janeiro: Rosa dos Tempos: Brasília:Nipas. Dutra, Yuri Frederico. (2006) A condição feminina perante o sistema de justiça criminal nos crimes contra os costumes. Grupo de trabalho: Movimentos sociais urbanos e o socialismo no 
século XXI . www.uel.br/grupo-pesquisa/gepal/.../yurifredericodutra.pdf; Scott, Joan W. (1990) Gênero: uma categoria útil de análise histórica. Tradução Guacira Lopes Louro. Educação e Realidade. Porto Alegre, v.16, n. 2, 9. Scott, Joan W. (2005) O enigma da igualdade in Estudos Feministas, Florianópolis, p.13-30.

${ }^{15}$ Brandt, Vinícius Caldeira. (1994). O trabalho encarcerado.Rio de Janeiro: Forense.p. 119 e 120.

${ }^{16}$ Lemgruber, Julita. (1983). Cemitério dos vivos: análise sociológica de uma prisão de mulheres. Rio de Janeiro: Achiamé. p. 119.

${ }^{17}$ Lemgruber, Julita. (1983). Cemitério dos vivos: análise sociológica de uma prisão de mulheres. Rio de Janeiro: Achiamé. p. 116.

${ }^{18}$ Julião, Elionaldo Fernandes. (2009). A ressocialização através do estudo e do trabalho no sistema penitenciário brasileiro.Tese (Doutorado) Instituto de Filosofia e Ciências Humanas. Universidade do Estado do Rio de Janeiro. p.112.

${ }^{19}$ Lemgruber, Julita. (1983). Cemitério dos vivos: análise sociológica de uma prisão de mulheres. Rio de Janeiro: Achiamé.p. 13

${ }^{20}$ Brandt, Vinícius Caldeira. (1994). O trabalho encarcerado. Rio de Janeiro: Forense.p. 119 e 120.p. 25.

${ }^{21}$ Julião, Elionaldo Fernandes. (2009). A ressocialização através do estudo e do trabalho no sistema penitenciário brasileiro. Tese (Doutorado) Instituto de Filosofia e Ciências Humanas. Universidade do Estado do Rio de Janeiro. p. 102.

${ }^{22}$ Lemgruber, Julita. (1983). Cemitério dos vivos: análise sociológica de uma prisão de mulheres. Rio de Janeiro: Achiamé. p. 120.

${ }^{23}$ Lemgruber, Julita. (1983). Cemitério dos vivos: análise sociológica de uma prisão de mulheres. Rio de Janeiro: Achiamé. p. 119

24; 25 e ${ }^{26}$ Data taken from a field research carried out at the São Luís Women's prison, in 2012. Project for the Analysis of the Effectiveness of Vocational Workshops on Resocialization of incarcerated Women at the Center for Social Inclusion of Sentenced Women - Confirmation in São Maranhão, by Yuri Dutra.

Tabela1: Percentage of Inmates in Vocational Programs in Brazil

\begin{tabular}{|c|c|c|c|}
\hline SEMESTER/YEAR & $\begin{array}{c}\text { Total Prison } \\
\text { Population in the } \\
\text { Prison System }\end{array}$ & $\begin{array}{c}\text { Number of inmates } \\
\text { in vocational } \\
\text { programs }\end{array}$ & $\begin{array}{l}\text { Percentage of inmates in vocational } \\
\text { programs }\end{array}$ \\
\hline \multirow{4}{*}{ Jul/Dec 2019} & \multirow{4}{*}{748.009} & \multirow{4}{*}{$144.211-19,28 \%$} & Male In-house Work $99.581-75,12 \%$ \\
\hline & & & Male Work Release 32.974 - 24,88\% \\
\hline & & & $\begin{array}{l}\text { Female In-house Work } 9.678 \text { - } \\
83,03 \%\end{array}$ \\
\hline & & & $\begin{array}{c}\text { Female Work Release } \\
1.978-16,7 \%\end{array}$ \\
\hline \multirow{4}{*}{ Jan/Jun 2019} & \multirow{4}{*}{752.277} & \multirow{4}{*}{$143.561-19,08 \%$} & Male In-house Work 97.316- 73,65\% \\
\hline & & & Male Work Release 34.817- 26,35\% \\
\hline & & & $\begin{array}{c}\text { Female In-house Work } 9.678 \text { - } \\
83,03 \%\end{array}$ \\
\hline & & & Female Work Release 1.850 - 16,19\% \\
\hline \multirow{4}{*}{ Jul/Dec 2018} & \multirow{4}{*}{725.332} & \multirow{4}{*}{$138.854-19,14 \%$} & $\begin{array}{c}\text { Male In-house Work } \\
92.823-73,69 \% \\
\end{array}$ \\
\hline & & & $\begin{array}{c}\text { Male Work Release } \\
33.145-26,31 \%\end{array}$ \\
\hline & & & $\begin{array}{c}\text { Female In-house Work } \\
10.579-82,1 \% \\
\end{array}$ \\
\hline & & & $\begin{array}{c}\text { Female Work Release } \\
2.307-17,9 \% \\
\end{array}$ \\
\hline \multirow{4}{*}{ Jan/Jun 2018} & \multirow{4}{*}{711.556} & \multirow{4}{*}{$130.087-18,28 \%$} & $\begin{array}{l}\text { Male In-house Work } \\
90.922-76,2 \%\end{array}$ \\
\hline & & & $\begin{array}{l}\text { Male Work Release } \\
9.200-85,45 \%\end{array}$ \\
\hline & & & $\begin{array}{c}\text { Female In-house Work } \\
9.200-85,45 \%\end{array}$ \\
\hline & & & $\begin{array}{c}\text { Female Work Release } \\
1.566-14,55 \%\end{array}$ \\
\hline
\end{tabular}




\begin{tabular}{|c|c|c|c|}
\hline SEMESTER/YEAR & $\begin{array}{c}\text { Total Prison } \\
\text { Population in the } \\
\text { Prison System }\end{array}$ & $\begin{array}{c}\text { Number of inmates } \\
\text { in vocational } \\
\text { programs }\end{array}$ & $\begin{array}{c}\text { Percentage of inmates in vocational } \\
\text { programs }\end{array}$ \\
& & & $\begin{array}{c}\text { Male In-house Work } \\
96569-79,12 \%\end{array}$ \\
\cline { 3 - 4 } & 704.576 & $133.989-19,02 \%$ & $\begin{array}{c}\text { Male Work Release } \\
25488-20,88 \%\end{array}$ \\
\cline { 3 - 4 } & & & $\begin{array}{c}\text { Female In-house Work } \\
10.462-87,68 \%\end{array}$ \\
& & & $\begin{array}{c}\text { Female Work Release } \\
1470-12,32 \%\end{array}$ \\
\hline
\end{tabular}

